\title{
DETECTION OF PARTIAL SHADING CONDITION AND EXTRACTION OF MAXIMUM POWER FROM SHADED PV ARRAY WITH FUZZY CONTROLLER
} \author{
SUDHAKAR A.V.V ${ }^{1}$, VODELA NAGA SANTHOSH ${ }^{2} \&$ MD. MUJAHID IRFAN ${ }^{3}$ \\ ${ }^{1,3}$ Associate Professor, Department of Electrical and Electronics Engineering, SR Engineering College, Warangal, Telangana,
} India

${ }^{2} P G$-Scholar, Department of Electrical and Electronics Engineering, S R Engineering College, Warangal, Telangana, India

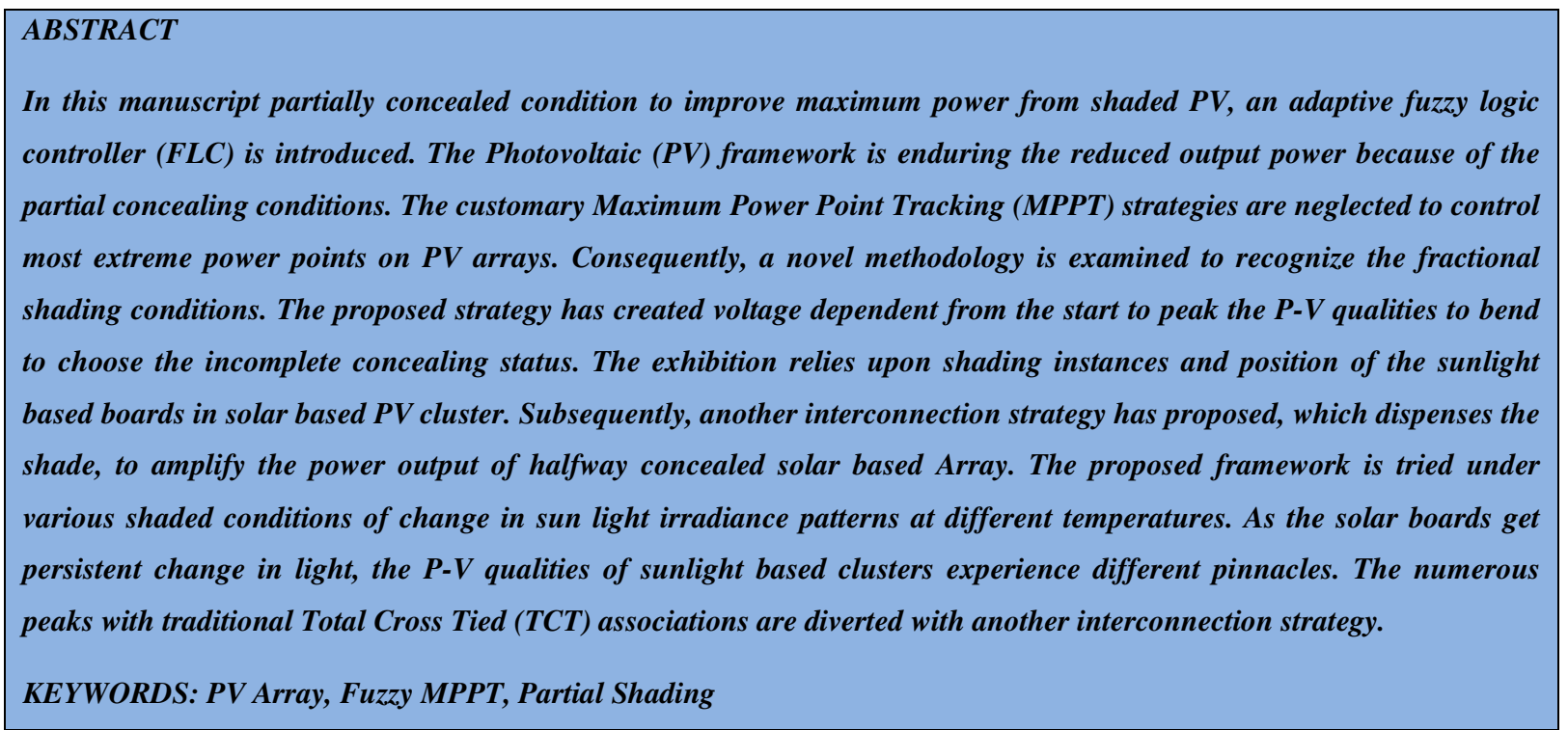

Received: Jun 08, 2020; Accepted: Jun 28, 2020; Published: Aug 19, 2020; Paper Id.: IJMPERDJUN2020817

\section{INTRODUCTION}

For fast developing of populace giving power to the public is greatest test before electrical designing. Power is going about as a spine to run any industry, so execution of ages becoming quick in each product. As of late the assimilation of sustainable power sources (RES) are duplicated in that sun oriented (PV) and wind is progressively predominant in view of its significances. Extraction greatest power from wind and sunlight based is conceivable by adaption of clever control methodologies. It upgrades the transient-consistent state execution of the half breed age. Wind quality has risen as surely one of the most significant and promising resources of sustainable quality. This needs additional transmission ability and better methodology of saving framework unwavering quality. Power ages are comprehensively accessible in two different ways, Conventional (CES) and Non-conventional (NCES). CES sources are hydro and thermal. In warm power age, crude material utilized is petroleum product (coal) might be exhausting in next two decades. For hydro Power plants primary source water and it is accessible in occasionally, so power age not done consistently. These two power ages infuse different fuel gases into nature and contaminate the climate. These issues a lot of degree defeat by utilizing NCES vitality sources. NCES sources (Renewable vitality sources-RVS) are greener and eco amicable nature, as sunlight based, wind and geo warm. Power produced consistently. It does not build up any fuel gases to produce the power. 
The improved exhibition of cross breed power age has been introduced in writing. That is fundamentally batteries (lead-corrosive batteries [1]) are the little scope RES frameworks, stores electrical vitality fills in as transitory vitality source where PV boards and wind vitality is not consistence. Like along these lines continuous power is provided to the heap. Vitality estimating is affirmed to the clients according to utilization of RES and battery network. Ideal estimating is included when RES sources are utilized productively. Sun based power is delegated Stand-alone PV and the network associated PV frameworks [2-4] The significant contrasts between these two sun oriented vitality discussion frameworks (SECS) are that in independent structures the PV yield is similarly offset with the heap request, Grid associated SECS both PV and matrix are liable for to accomplish the heap request. When non direct loads, for example, three stage connect rectifier is associated in the circuit lattice coordinate PV structures are endured with power quality worries as sounds, voltage lists, voltage swells and so on. This power quality issues are happened due nearness of non-straight loads in the dissemination.

Power quality upgrading in matrix incorporating PV-wind is portrayed [5-7], the nonlinearities, music are happened primarily because of essence of non-straight loads in the system. Most extreme

Power removes from sun powered and wind with utilizing Petrub-Obseravation, steady conductance and fuzzy controllers [13-15]. The fuzzy MPPT calculation is utilized and reproduction results are examined by B.Subuddi [8], demonstrated fuzzy MPPT functions admirably contrasted with different PI control to controlling the exchanging of VSC.

The buck converter and buck support converters [11] are the transcendent and much of the time utilized Dc-Dc converter. The straightforward desires for these circuits depend on the info dc voltage being cleaved with a specific help cycle to accomplish wanted output voltage levels. For the most part, the exchanging recurrence is kept at steady length, and the beat width must be adjusted. These circuits are anything but difficult to create however experience the ill effects of disadvantages that hinder their utilization in applications with higher power and higher voltage. A total evaluation and audit of dc-dc help converter strategies for the photovoltaic framework was extended in this article. The appraisal of the $\mathrm{dc}-\mathrm{dc}$ buck converter, dc-dc support converter, and dc-dc buck-help converter was likewise marginally explained. It is derived from the investigation that dc-dc support converters [12] have significant points of interest over different converters because of their improved powerful proficiency and the least expensive arrangement techniques.

\section{SYSTEM CONFIGURATION}

The schematic diagram of PV array is shown in figure.1.

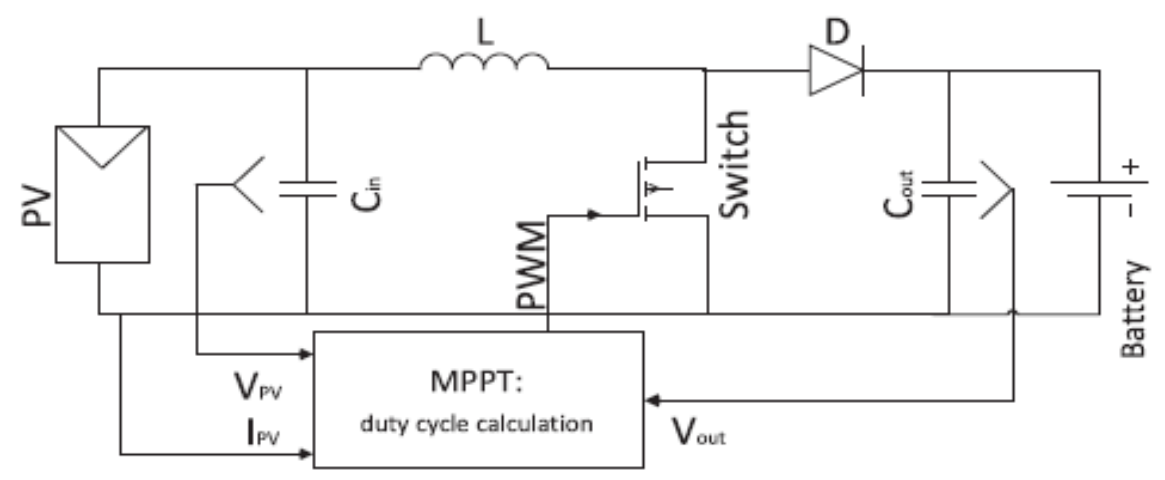

Figure 1: Fuzzy Based PV Array with Battery. 


\section{Design of PV Array}

The solar cell basically speaks to current source with shunt by diode. Its setup is appeared in figure.2. where shunt- series arrangement resistors are ensuring to the PV cell.

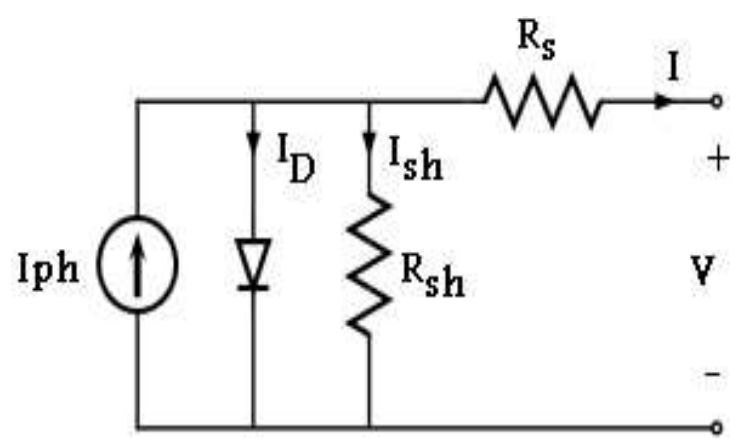

Figure 2: Structure of PV Cell.

The load current (I), mathematically expressed as

$$
\mathrm{I}=I_{p h}-I_{s}\left(\exp q \frac{\left(v+R_{s} I\right)}{N K T}\right)-1-\left(\frac{v+R_{s} I}{R_{s h}}\right)
$$

Where

$I p h=$ solar current

Rseand Rshare the series and shunt resistors

$q=$ electron charge

$V=$ voltage available at diode

$K=$ Boltzmann's constant

$T=$ temperature

To obtain the desired voltage from PV cell ' $n$ ' no. of PV cells are connected in cascade manner

$$
\begin{aligned}
& \mathrm{v}_{\text {seriza }}=\sum_{\mathrm{j}=1}^{\mathrm{n}} \mathrm{V}_{\mathrm{i}}=\mathrm{v}_{1}+\mathrm{V}_{2}+\ldots \ldots \ldots+\mathrm{v}_{\mathrm{n}} \mathrm{f} \\
& V_{\text {seriesoc }}=\sum_{i=1}^{n} V_{i}=V_{o c 1}+V_{o c 2}+\ldots \ldots \ldots .+V_{\text {ocn }} \text { for } I=0 \\
& \mathbb{I}_{\text {parallel }}=\sum_{\mathrm{j}=1}^{n} \mathrm{I}_{\mathrm{j}}=\mathrm{I}_{1}+\mathbb{I}_{2}+\ldots \ldots \ldots+\mathbb{I}_{\mathrm{n}} \\
& \mathrm{V}_{\text {parallel }}=\mathrm{V}_{1}=\mathrm{V}_{2}=\ldots \ldots \ldots=\mathrm{V}_{\mathrm{B}}
\end{aligned}
$$

\section{Fuzzy MPPT Algorithm}

The specialists structured and presented various geographies for dc-dc support converters to fortify fundamental issues, for example, gadget efficiencies, gains in voltage and in the ability to convey power. There are barely any strategies that depict venturing up the voltage without the requirement for longer help cycles and may utilize different cell interleaving to rise the output power. Significant characterizations of dc-dc support converters have been investigated utilizing their operational standards to distinguish the examination hole in the dc-dc help converters region. It is finished up from the 
investigation that dc-dc support converters [13-15] will have magnificent points of interest over different converters.. Presently a day's controlled exchanging design is finished by fuzzy MPPT calculation to remove the pinnacle power from the PV module. This fuzzy based DC converter gives less oscillatory voltage to the arrangement VSCs which improves dynamic execution and by and large effectiveness of the PS organize. The structure of fuzzy based DC-DC converter is appeared in Fig. 3.

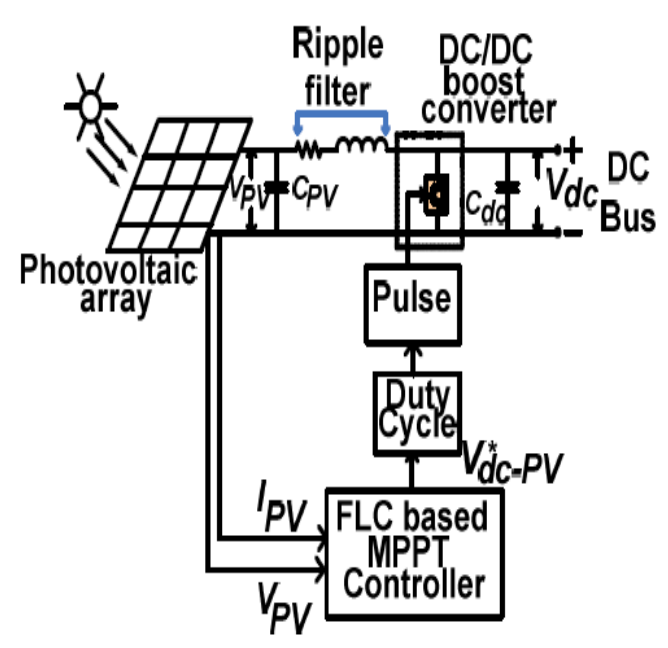

Figure 3: Structure of Fuzzy Based Boost Converter.

\section{PROPOSED CONTROL SCHEME}

The general framework execution of matrix associated hybrid power is controlling exchanging pattern of VSC. This VSC is worked with heartbeat creation. This heartbeat age is actuated by smart fuzzy PI settings. Where fuzzy is worked w.r.t to variety of blunder signal. The standards are has been referenced in underneath the proposed fuzzy control plot is appeared in fig.4.

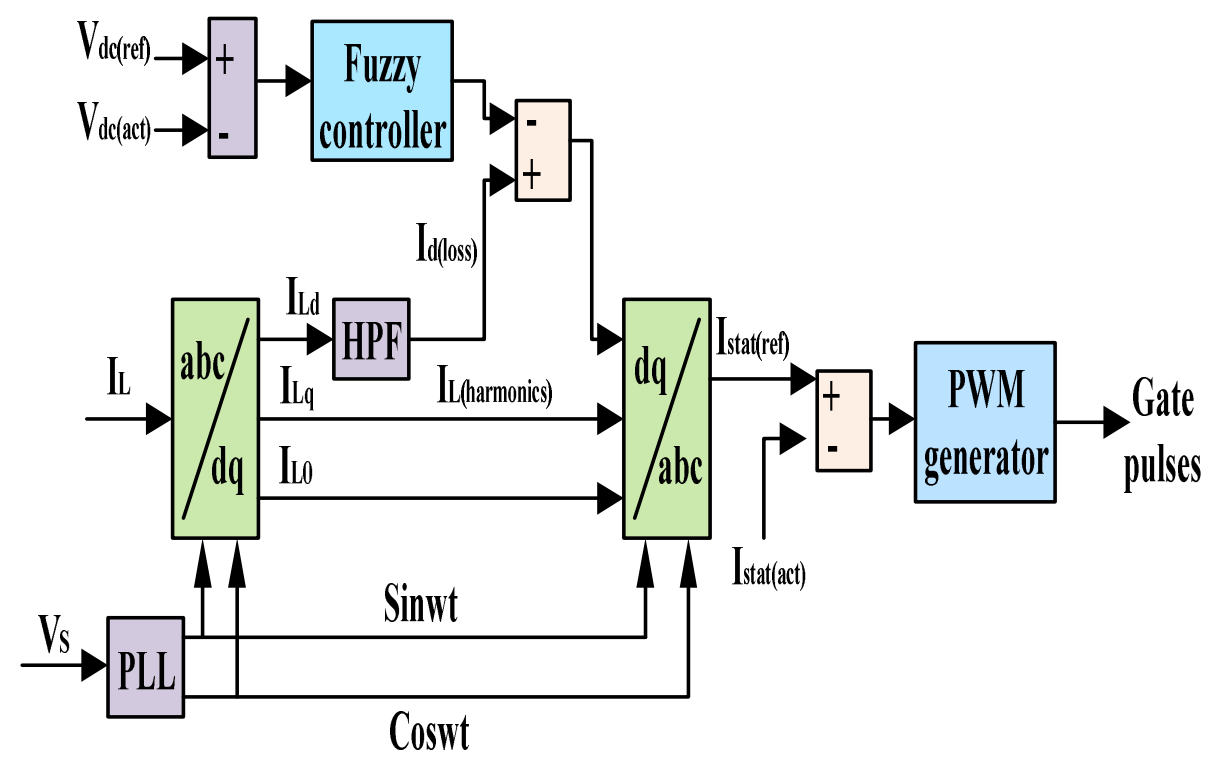

Figure 4: Proposed Fuzzy Control Scheme. 
Fuzzy logic rationale contrasts with both in idea and substance from conventional multivalve legitimate frameworks systems. Such as NB, NM, NS, ZE, PS, PM and PB those are stands for negative big, negative medium, negative small, zero positive small, positive medium, positive big respectively. The Fuzzy legitimates are shown in triangles in figure.5

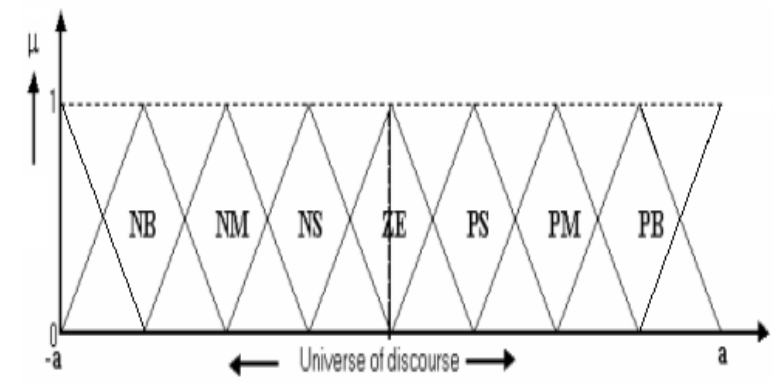

Figure 5: Fuzzy Legitimate Frame Work for 50\% Overlap Varying -a to +a.

\section{SIMULATION RESULTS}

The MATLAB model of fuzzy based PV array with grid connected is shown in figure.6.

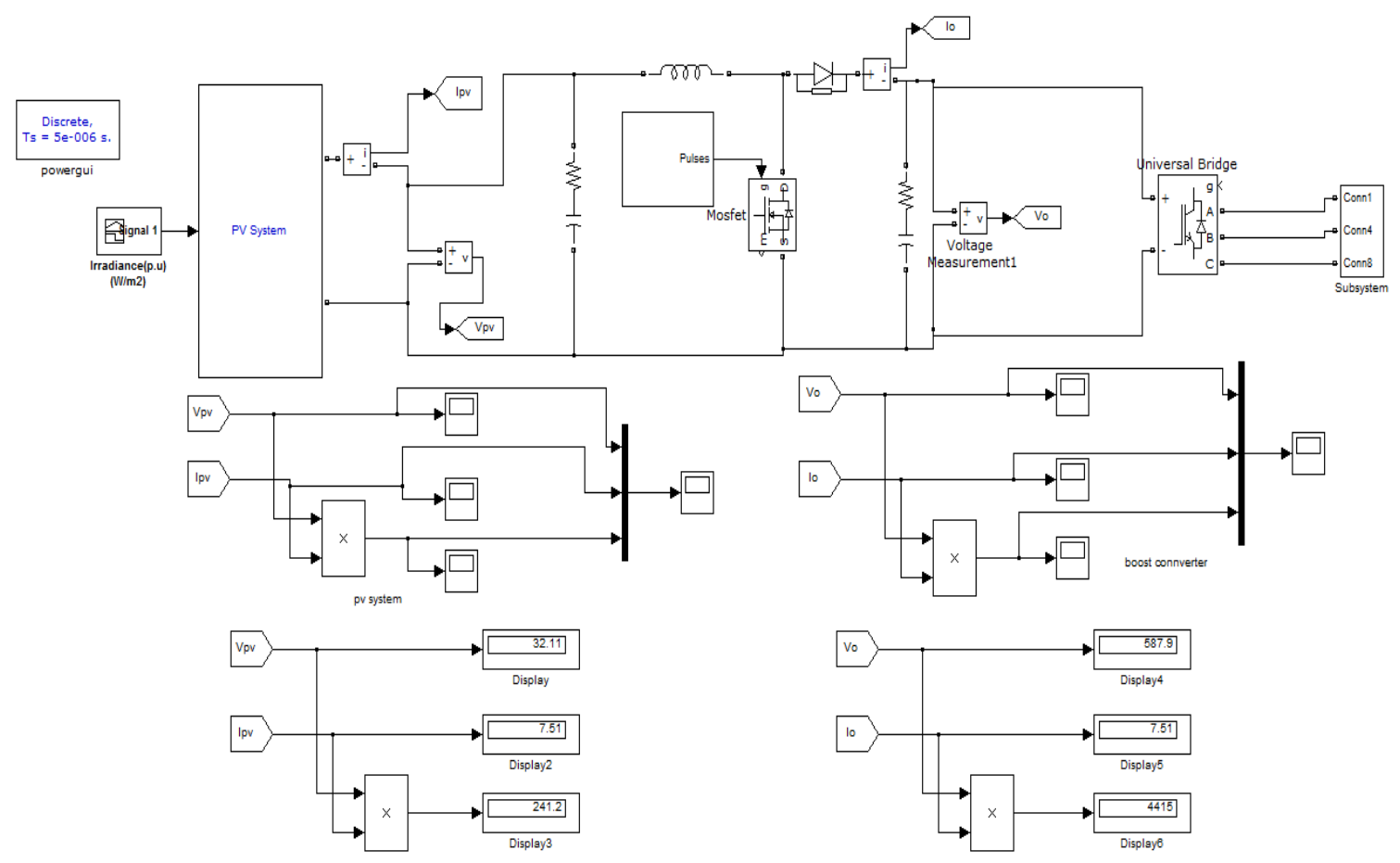

Figure 6: Fuzzy Based PV Array. 
I-V characteristics and P-V characteristics of PV array are shown in figure.7a. and figure.7b

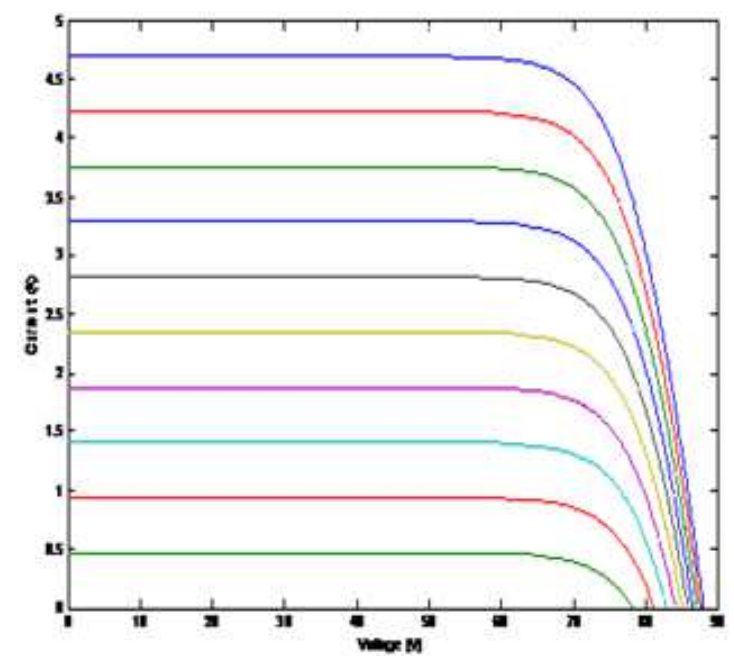

Figure 7a: I-V Characteristics of Solar Array.

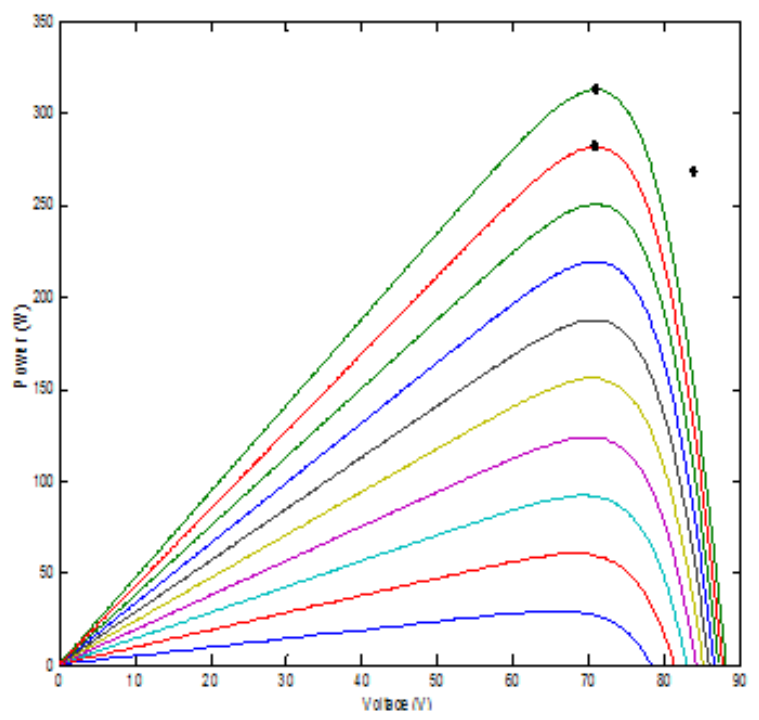

Figure 7b: P-V Characteristics of Solar Array.

At the point when all the modules get uniform irradiance, the string Power-Voltage (P-V) trademark has an interesting top under fractional shading conditions; the P-V bend of the string builds up different maxima. A large portion of the GMPPT strategies proposed in writing are unequipped for recognizing uniform and halfway concealing, and accordingly utilize worldwide hunt significantly under uniform insolation conditions. The progress from uniform irradiance to incomplete concealing I-V and P-V attributes are appeared in beneath figure.8a and figure $8 \mathrm{~b}$ 

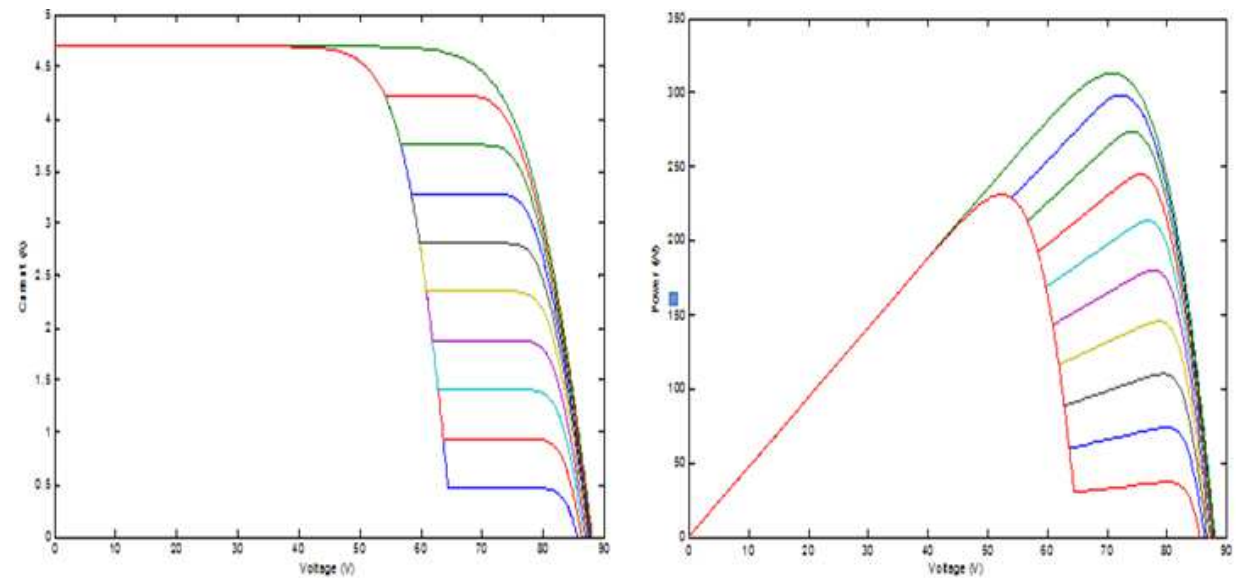

Figure 8: I-V and P-V Characteristics of PV Array Under Non Uniform Irradiance.

The output voltage, current, power of PV array and duty cycle is shown in figure.9a. to figure.9d

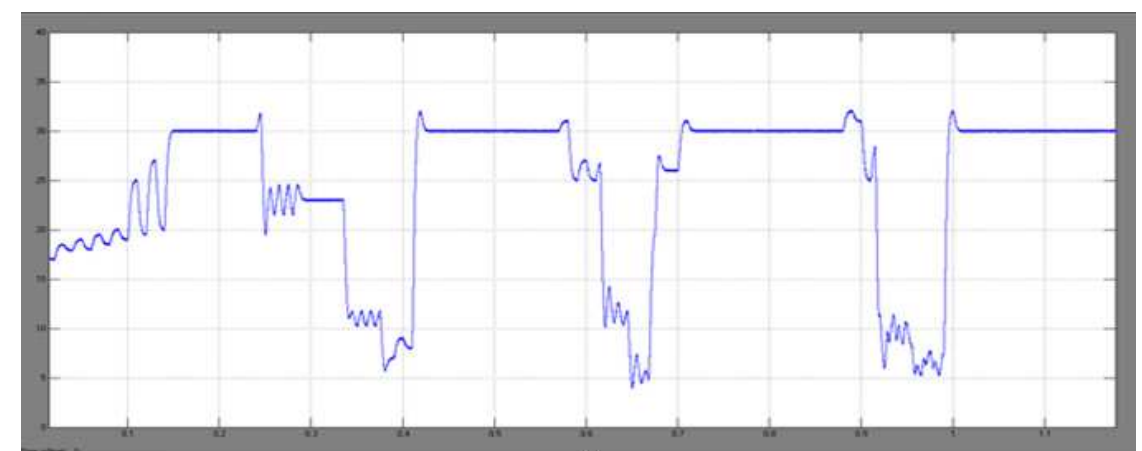

(a)

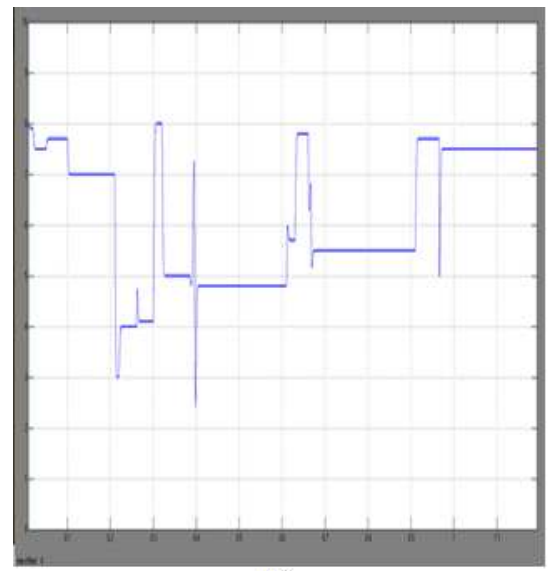

(b)

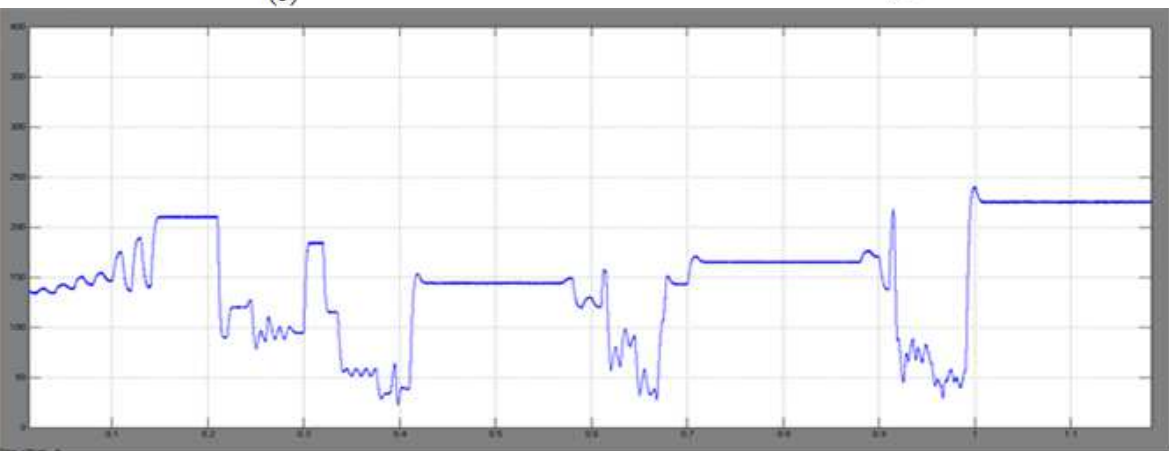

(c)

Figure 9: PV Array's. 
Y - Axis

(a) Voltage, (b) Current, (c) Power, and (d) Duty Cycle Wave Form

\section{Axis}

Time in $\mathrm{ms}$

The output voltage, current, power of PV array and duty cycle is shown in figure.10a. to figure.10d

\begin{tabular}{|l|l|l|l|l|l|l|l|}
\hline & & & & & & & \\
\\
\hline
\end{tabular}

(a)

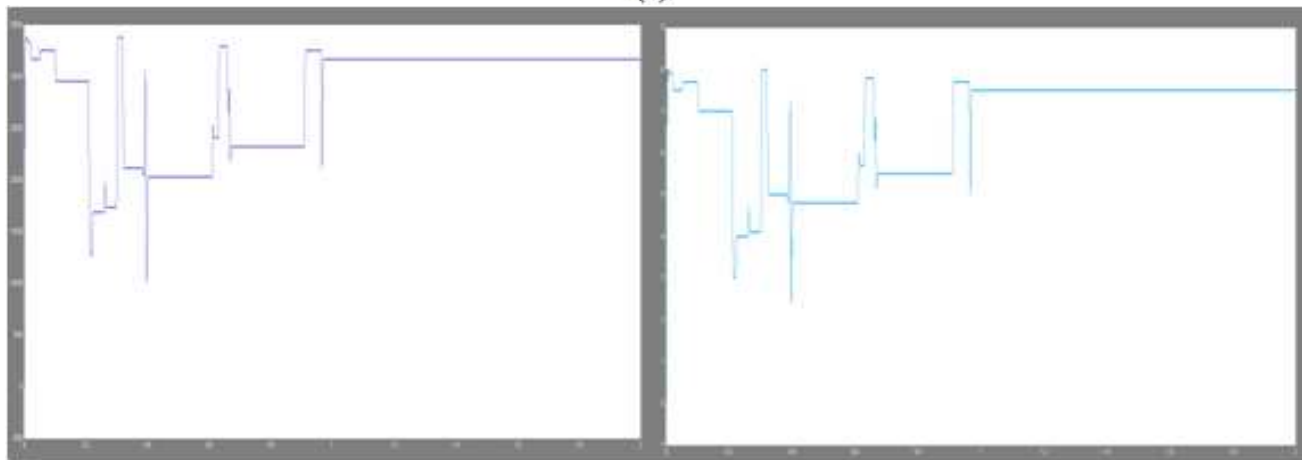

(b)

(c)

Figure 10: FLC Based Converter (a) Voltage, (b) Current, (c) Power.

\section{CONCLUSIONS}

This manuscript presents a novel interconnection method to enhance the output magnitude of PV array i.e. solar output voltage and currents. To establish the improvement in the efficiency of the shaded PV array with proposed technique, the detailed explanation for changing panel locations without changing electrical connections is illustrated with tables and figures. Simulation results clearly confirm and demonstrate that the magic square connection gives better power output than TCT configuration. The fuzzy based MPPT method successfully eliminated the local peaks presented in TCT configuration, which makes ease for the maximum power point tracking.

\section{REFERENCES}

1. IEEE Guide for Selecting, Charging, Testing, and Evaluating Lead-Acid Batteries Used in Stand-Alone Photovoltaic (PV) Systems," in IEEE P1361/D5, February 2014, vol., no., pp.1-36, 16 June 2014 
2. K. Javed, H. Ashfaq and R. Singh, "Application of Supercapacitor as Hybrid Energy Storage Device in Stand-alone PV System," 2019 International Conference on Power Electronics, Control and Automation (ICPECA), New Delhi, India, 2019, pp. $1-4$.

3. S. K. Kollimalla, M. K. Mishra and N. L. Narasamma, "Design and Analysis of Novel Control Strategy for Battery and Supercapacitor Storage System," in IEEE Transactions on Sustainable Energy, vol. 5, no. 4, pp. 1137-1144, Oct. 2014.

4. Patel, G., DILIP B. Patel, and KINJAL M. Paghdal."Analysis of P\&O MPPT algorithm for PV system." International Journal of Electrical and Electronics Engineering (IJEEE) 5.6 (2016): 1-10.

5. A. Merabet, K. Tawfique Ahmed, H. Ibrahim, R. Beguenane and A. M. Y. M. Ghias, "Energy management and control system for laboratory scale microgrid based wind-PV-battery”, IEEE Trans. Sustain. Ener., vol. 8, no. 1, pp. 145-154, 2017.

6. A. Ramyar, H. Iman-Eini and S. Farhangi, "Global Maximum Power Point Tracking Method for Photovoltaic Arrays Under Partial Shading Conditions," IEEE Trans. Ind. Elect., vol. 64, no. 4, pp. 2855-2864, April 2017.

7. Kumari, K. Karuna, and P. V. Sridevi. "Phase-only Synthesis of Linear Microstrip Patch Antenna Array using Improved Local Search Particle Swarm Optimization." International Journal of Applied Engineering Research 12.6 (2017): 818-832.

8. K. Basaran, N. S. Cetin and S. Borekci, "Energy management for on-grid and off-grid wind/PV and battery hybrid systems," in IET Renewable Power Generation, vol. 11, no. 5, pp. 642-649, 1242017.

9. Yaow-Ming Chen, Chung-Sheng Cheng and Hsu-Chin Wu, "Grid-connected hybrid PV/wind power generation system with improved DC bus voltage regulation strategy," Twenty-First Annual IEEE Applied Power Electronics Conference and Exposition, 2006. APEC '06., Dallas, TX, 2006

10. S. Mohanty, B. Subudhi and P. K. Ray, "A New MPPT Design Using Grey Wolf Optimization Technique for Photovoltaic System Under Partial Shading Conditions," in IEEE Transactions on Sustainable Energy, vol. 7, no. 1, pp. 181-188, Jan. 2016.

11. Sachin, Chaudhari, and Kaumil B. Shah. "Solar Photovoltaic Fed Induction Motor for Water Pumping System Using MPPT Algorithm. "International Journal of Electrical and Electronics Engineering (IJEEE) 7.3, Apr - May 2018, 31-42

12. Abinaya.I,S.D.SundarsinghJebaseelan and C.N.Ravi, "Reactive Power Compenstion in Grid System using STATCOM with Closed loop Control,' Indian Journal of Science and Technology, Vol 9(6), pp 1- 4, February 2016.

13. Marlin.S, S.D.SundarsinghJebaseelan, B. Padmanabhan and G.Nagarajan, "Power Quality Improvement for Thirty Bus system using UPFC and TCSC, ”Indian Journal of Science and Technology, Vol7 (9), pp 1316 - 1320, September 2014.

14. A.V.V. Sudhakar, D. Rajababu, B. Sathyavani, "Analysis of the Power Losses in Both DC Side and AC Side Cascaded Converters", International Journal of Recent Technology and Engineering (IJRTE), ISSN: 2277-3878,Volume-8, Issue- 1C2, May 2019, pp. 897-899.

15. Kishore, S. Naga, et al. "Design, Performance Evaluation and Cost Analysis of Solar PV-System with Diesel Generator in Hybrid Power System. "International Journal of Mechanical Engineering (IJME) 4. 2, Mar 2015, 9-18

16. D. Rajababu, A.V.V. Sudhakar, B. Sathyavani, "Development of Technology for High-Power Industry Converters", International Journal of Innovative Technology and Exploring Engineering (IJITEE), Vol. 8, No. 10, August 2019, ISSN: 2278-3075. DOI: 10.35940/ijitee.J9464.0881019.

17. Rajababu D. and Raghu Ram K., "Load current observer and adaptive voltage controller for standalone wind energy system with linear and non-linear loads", International Journal of Engineering and Advanced Technology, vol. 9, no. 1, (2019), pp. 5491-5496. 
18. Rajababu D. and Raghu Ram K., "Voltage control of isolated wind energy conversion system using adaptive voltage controller for non-linear loads", International Journal of Recent Technology and Engineering, vol. 8, no. 3, (2019), pp. 3214-3219.

19. Rajababu D. and Raghu Ram K., "Voltage control strategy for three-phase inverter connected standalone wind energy conversion systems", International Journal of Innovative Technology and Exploring Engineering, vol. 8, no. 11, (2019), pp. 2164-2168. 